\title{
Analysis Employee Productivity Based on the Characteristics of Workload, Motivation and Work Stress in Bakti Mulia Hospitals Muncar District Banyuwangi
}

\section{Zainudin Efendi}

Magister of Public Health Program of Stikes Surya Mitra Husada Kediri

Email:

zainudinefendi41@gmail.com
Received: March 12, 2019

Accepted : April 13, 2019

Published : May 10, 2019

\begin{abstract}
Spotlight on the performance of nurses is a problem that must be addressed immediately, because nursing services determine the quality of hospital services. Poor performance will affect the low service, patients feel less comfortable and not satisfied that affect the productivity of work. Some causes of low work productivity include workload, motivation and work stress. The purpose of this research is to know the factors that influence productivity at Bakti Mulia Hospital Muncar of Banyuwangi Regency. The research design used was cross sectional. The research population is all employees at Bakti Mulia Muncar Banyuwangi Hospital as many as 133 people and sample size 100 people. The sampling technique using simple random sampling. Data collection using questioner then analyzed using logistic regression. The results show that there is the influence of the workload on work productivity $(\mathrm{p}=0.012$; $\mathrm{OR}=0,314)$, there is the influence of motivation to work productivity $(\mathrm{p}=0.035$; $\mathrm{OR}=0,035)$, there is the effect of work stress on work productivity at Bakti Mulia Hospital Muncar Banyuwang District $(p=0,039$; OR $=0,102)$. While the most dominant factors that affect the productivity of employees at Bakti Mulia Hospital Muncar Banyuwangi regency is the work load. Based on the research, the management of hospital should consider the work load factor, motivation and work stress to increase work productivity and also to improve the facilities and infrastructures that support for the employees in the work.
\end{abstract}

Keywords: Employee productivity, workload, motivation and job stress

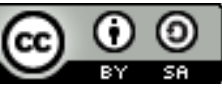

This is an open-acces article distributed under the terms of the Creative Commons Attribution-ShareAlike 4.0 International License.

\section{INTRODUCTION}

The hospital is one of the forms of health facilities, both organized by the government and / or the community functioning to carry out basic health efforts or referral health and supporting health efforts. Hospitals in carrying out their functions are expected to always pay attention to social functions in providing health services to the community (Rahman, 2015).

Spotlight on the performance of nurses is a problem that must be addressed immediately, because nursing services determine the quality of hospital services. Poor performance will impact on low levels of service, patients feel uncomfortable and dissatisfied (Aprilia, 2017). 
Nurse's workload is also a problem due to work load imbalance. Workload fluctuation is another form of work stress generator, because in the work load received by the nurse always experienced ups and downs, sometimes mild even sometimes can be overloaded work. The situation can be encountered in labor who work in hospitals, especially nurses. Such improper circumstances can lead to anxiety, job dissatisfaction and the tendency to leave work. What affects the workload of the nurse is the changing patient condition, the average number of hours of care needed to provide direct service to the patient and the documentation of nursing care (Kusmiati, 2003 in Sumangando 2017), the negative consequences of this problem, which is not as expected as the nurse is still there. Excessive workload is very influential on the productivity of health workers and of course affect the productivity of the hospital itself.

Motivation can be viewed as a change of energy in a person characterized by a feeling and preceded by a response to the goal, motivation is a basic drive that moves a person or a desire to devote all the energy karen a goal, as revealed by Mangkunegara (2012) motivation is a condition of a tau propelling energy self-directed or directed employees to achieve its goal $\mathrm{n}$ organization. The positive mental attitude of employees to work situations that strengthen the motivation to work to achieve maximum performance.

In addition to workload problems, work stress factors also play an important role in efforts to improve the performance of nurses. When there is no stress, there is no work challenge. Conversely, if stress is too high, performance will decrease because stress disrupts the implementation of the work. Job stress causes the nurse to lose the ability to control it. The most extreme consequence is that performance is low, nurses lose heart in work, despair, and exit or refuse to work to avoid stress. According Siagian (2012) if stress can not be anticipated properly and correctly it will result in the inability of a person to interact positively with the environment, both in the work environment and outside work.

Bakti Mulia Hospital is the only one hospital in walayah muncar that was established in 2009 and has been accredited in 2016, Bakti Mulia Hospital is PT Sari Husada Santoso Hospital which is very demanding high discipline work from paramedics to face the competition in service world, which has been more than 8 years has been proven by PT Sari Husada Santoso, it is very demanding Hospital to continuously provide good service to the community. On the other hand there is a significant gap between the quality of service and the number of employees available. The number of employees is closely related to the workload received by employees. If the workload is light, this will not be a problem. However, if the workload received is excessive can cause employees less motivated in working so that memincu emergence of stress work. With the workload, motivation and stress of this work can cause employee productivity affect can increase or decrease.

Based on the above description, the researcher is interested to see further some causes of low work productivity such as work load and work stress, so the researcher conducts research with the title of employee productivity analysis based on the characteristics of workload, motivation and work stress at Bakti Mulia Hospital Muncar Banyuwangi.

\section{MATERIALS AND METHODS}

The design used in this study is cross-sectional. The population is all employees at Bakti Mulia Muncar Banyuwangi Hospital as many as 133 people the sample size is 100 respondents using simple random sampling technique. Independent research variables are workload, motivation and job stress. Dependent variable is work productivity. Data were collected using questionnaire, then data were analyzed using logistic regression test with a significance level of $\alpha \leq 0.05$. 


\section{RESULTS}

Table 1 Frequency Distribution by Workload

\begin{tabular}{ccc}
\hline Workload & $\mathrm{n}$ & $\mathrm{f}(\%)$ \\
\hline High & 58 & 58 \\
\hline Medium & 41 & 41 \\
\hline Low & 1 & 1 \\
\hline Total & 100 & 100 \\
\hline
\end{tabular}

Source: Primary data of research in 2018

Based on table 1 shows that of 100 respondents most of the high category workload that is as much as 58 respondents (58\%).

Table 2. Frequency Distribution Based on Motivation

\begin{tabular}{ccc}
\hline Motivation & $\mathrm{n}$ & $\mathrm{f}(\%)$ \\
\hline High & 62 & 62 \\
\hline Medium & 36 & 36 \\
\hline Low & 2 & 2 \\
\hline Total & 100 & 100 \\
\hline
\end{tabular}

Source: Primary data of research in 2018

Based on table 2 shows that from 100 respondents most of the high category motivation as many as 63 respondents $(63 \%)$.

Table 3. Frequency Distribution Based on Working Stress

\begin{tabular}{ccc}
\hline Job Stress & $\mathrm{n}$ & $\mathrm{f}(\%)$ \\
\hline High & - & - \\
\hline Medium & 9 & 9 \\
\hline Low & 91 & 91 \\
\hline Total & 100 & 100 \\
\hline
\end{tabular}

Source: Primary data of research in 2018

Based on the table 3 indicates that from 100 respondents most of the work stress of low category that is as much $91(91 \%)$.

Table 4. Frequency Distribution Based on Productivity

\begin{tabular}{ccc}
\hline Productivity & $\mathrm{n}$ & $\mathrm{f}(\%)$ \\
\hline Not Productivity & 46 & 46 \\
\hline Productivity & 54 & 54 \\
\hline Total & 100 & 100 \\
\hline
\end{tabular}

Source: Primary data of research in 2018

Based on table 4 shows that from 100 respondents most productivity productive working category that is as much as 54 respondents $(54 \%)$. 
Table 5 Pseudo R-Square Test Results

Pseudo R-Square

\begin{tabular}{cc}
\hline Cox and Snell &, 198 \\
\hline Nagelkerke &, 265 \\
\hline McFadden &, 160 \\
\hline
\end{tabular}

The results of statistical tests in this study obtained Pseudo R-Square value at Nagelkerke of 0.265 this means workload, motivation and work stress affect work productivity d i Bakti Mulia Hospital Muncar Banyuwangi amounted to $26.5 \%$ and the rest influenced by other factors by $73.5 \%$. Based on logistic regression analysis, it is found that from three variables after logistic regression test, there are two variables that influence work productivity at Bakti Mulia Muncar Hospital, Banyuwangi Regency, ie work load ( $\mathrm{p}=0,00$; OR $=0,303$ ). This implies that if the employee has a high workload, then the employee has less productive risk in working 0.303 times greater than employees who have low workload. Working stress $(\mathrm{p}=0.042$; OR $=0.105)$. This implies that if employees have high job stress, then the employee has less productive risk in working 0.105 times greater than employees who have low job stress. So it can be concluded that the most dominant factor affect $\mathrm{Y}$ (productivity) is the work load factor with the effect of 0.303 times.

\section{DISCUSSION}

\section{A. Influence workload with employee work productivity}

Based on the results of this study showed that from 100 respondents almost half the high category workload and productivity productivity working category (39\%), and from the results of regression tests logistics obtained $\mathrm{p}=0.012(\mathrm{OR}=0.314)$. This implies that if a high workload on work productivity, the opportunity to increase productivity by 0,314 times greater than the low workload. Because the value of $p<0.05$, so $\mathrm{H} 1$ accepted and Ho rejected means there is influence workload with employee productivity at Bakti Mulia Hospital Muncar Banyuwangi District.

The results of this study are similar to the results of previous research conducted by Afia (2013) which examines the contribution of workload, work disiplion, relationships with colleagues on work productivity at PT. Viccon Modern Industry. The result of F-test is 22,202> Ftable 2,75, it means that all independent variables ie workload (X1), work discipline (X2), and relationship with coworkers (X3) together contribute positively to variable bound namely the productivity of work (Y). The significance value of the F-test at $0.000<$ from its significance level of 0.05 means that the F-test is significant. Then $\mathrm{H} 4$ is accepted and it can be concluded that all the independent variables ie workload X1, work discipline (X2), and relationship with coworkers (X3) together contribute positively significant to the dependent variable ie work productivity (Y).

Workload can be defined as a difference between a worker's capacities or ability with the job demands to be faced. In general, the optimum workload level will be achieved if there is no excessive pressure and tension both physically and mentally (Tarwaka 2010). Meanwhile, according to Menpan (Dhania, 2010) workload is a set or a number of activities that must be completed by an organizational unit or holder position within a certain period.

Factors affecting the work load in Masna's research (2017) are as follows : External factors are burdens that come from outside the worker's body, such as tasks performed that are physical such as work stations, spatial, workplace, tools and facilities work, working conditions, work attitude, whereas mental tasks such as the complexity of work, the degree of difficulty of work, training or education gained, job responsibilities; Work organization such as working time, rest period, rotational work, night work, wage system, organizational structure model, assignment and authority; and the working environment is the physical work environment, chemical environment, biological work environment, and psychological work environment. While the internal factor is a factor derived from the body due to the reaction of external workload. The body's reaction is called a strain, the severity of the strain can be judged both objectively and subjectively. Internal factors include somatic factors 
(sex, age, body size, nutritional status, health condition), psychological factors (motivation, perception, trust, desire and satisfaction).

Employee workload will be a problem in case of work load imbalance as well as Bakti Mulia hospital. The situation can cause anxiety, work discontent and the tendency to leave work. Excessive workload is also very influential on the productivity of health workers and of course affect the productivity of the hospital itself. Therefore, the workload to be carried out by employees should be evenly distributed, so avoid an employee who has too much workload or too little. In this study the parameters used to measure the workload of employees with the method of work sampling where the indicators used are personnel activities, personnel functions and duties, productive activities and patterns of work mind associated with time and work schedule.

The number of jobs that exceed the capacity to drain the physical energy or cognitive ability of the employees themselves, causing the physical condition of employees easily tired and tense. Although the workload is high, but employee productivity is still (not decreased), this indicates that the activities carried out regularly and regularly can affect the physical condition so that employees do not feel burdened with the work he is doing today. This is in accordance with the $\mathrm{h}$ ic research that the higher the workload will be followed by work productivity.

\section{B. Influence motivation with employee productivity}

Based on the results of research shows that from 100 respondents almost half of the high category of motivation and productivity of productive work category (40\%), and from the results of regression tests logistics obtained $\mathrm{p}=0.035(\mathrm{OR}=0.385)$. This implies that if the high motivation of work productivity, then the opportunity to increase productivity of 0,385 times greater than the low motivation. Because the value of $p<0.05$, so $\mathrm{H} 1$ accepted and Ho rejected means there is influence motivation with employee productivity at Bakti Mulia Hospital Muncar Banyuwangi regency.

The results of this study are similar to previous research conducted by Hutabarat (2016) which examines the influence of motivation to increase employee productivity at PT. Jasa Marga (Persero) tbk Medan. The results of the research is known coefficient of determination value of 0.143 . This value means motivation factor able to explain work productivity variable equal to $14,3 \%$, the rest equal to $85,7 \%$ explained by other factor. Based on the result of research, motivation variable have positive and significant effect to employee work productivity that is value $\rho=0,000<0,005$.

Motivation is a factor that encourages a person to perform a certain activity, motivation is often interpreted also as a driver of one's behavior (Sutrisno, 2013). Motivation is the thing that causes, distributes and supports human behavior, in order to work hard and enthusiastically achieve optimal results (Hasibuan, 2012).

The purpose of motivation according to Sunyoto (2013) is as follows: encourage employee passion and morale, improve employee morale and job satisfaction, improve employee productivity, maintain employee loyalty and stability, improve discipline and reduce employee absenteeism, streamline employee procurement, atmosphere and good working relationships, increase creativity and employee participation, improve employee welfare, enhance employees' sense of responsibility for their duties. According Sunyoto (2013) factors that influence the motivation there are seven namely: promotion, job performance, work itself, rewards, responsibility, recognition, success in work.

Giving motivation to employees is expected to improve employee productivity. Provision of motivation is not solely in the form of material, but also can be non-material such as promotions, awards for achievement, recognition of skills and so forth. It is very necessary to spur the passion for the employee as well as motivation is a demands of the human factor on the needs and desires to solve a challenge that must be faced. Because the recognition is one of the compensation that must be given by the company to employees who do have a certain skill and can perform the job well as well.

\section{Influence work stress with employee work productivity}

Based on Table 4:10 shows that from 100 respondents almost half the work stress category low and productivity productivity working category $(41 \%)$, and from the results of regression tests logistics obtained $\mathrm{p}=0.039(\mathrm{OR}=0.102)$. This implies that if the lower work stress on work 
productivity, the opportunity to increase productivity by 0,102 times greater than a high workload. Because the value of $p<0.05$, so $\mathrm{H} 1$ accepted and Ho rejected means there is influence of work stress with employee productivity at Bakti Mulia Hospital Muncar of Banyuwangi Regency.

The results of this study are similar to the results of research conducted by Saputri (2012) which examines the relationship between job stress with employee productivity. Based on the calculation results obtained correlation coefficient $(r)=-0.514 ; p=0,000(p<0.01)$. These results indicate there is a very significant negative relationship between job stress with work productivity. The higher the job stress the lower the productivity of work, so otherwise the lower the work stress the higher the productivity of work.

Stress is an inability to cope with the threats faced by the mental, physical, emotional and spiritual human beings who may someday affect the physical health of the human being. Stress is a dynamic condition in which an individual is confronted with an opportunity, constraint or demand that is associated with what is desired or the result is prescribed as uncertain and important (Robbins, 2011). Job stress is a condition in which there are one or several factors in the workplace that interact with the work that interfere with physiological and behavioral conditions (Suwatno and Priansa, 2011).

Stress does not just arise but the causes of stress arise generally followed by factors that affect the psychological events of a person, and events that occur outside of his ability so that conditions have depressed his soul. If well managed work stress can actually increase the productivity and individual maturity. Conversely, if the individual is not able to manage the stress he experienced then tends to become unproductive (Sekarwangi \& Meiyanto, 2014).

One of the factors that affect the work productivity is job stress. Job stress is a natural aspect that can not be denied by every employee in the workplace. The state of work stress affects the state of the company or organization and also against employees, but the stress of this work not only raises a negative thing there are also positive things that can be from work stress such as increasing motivation, aroused to work harder, or get inspired to become a better person again. But in negative terms of work stress many of them are harmful and harmful. Stress in an individual can have an emotional, anxious, uninspired, lazy, less creative, and conflict-sensitive and even increase blood pressure and headaches. If stress can not be anticipated properly and correctly it will result in the inability of a person to interact positively with the environment, both in the work environment and outside work. Therefore, there should be some efforts to be done by a company management in this case the hospital to avoid or reduce the level of stress on employees, so that the work process is not hampered. The lower the work stress of employees then the level of work productivity will be higher otherwise the higher the employee stress the productivity will decrease.

\section{The most dominant factor affecting employee productivity}

Based acyl h logistic regression statistical test values obtained on the work load ( $\mathrm{p}=0.11$; OR $=0.303)$. This implies that if the employee has a high workload, then the employee has less productive risk in working 0.303 times greater than employees who have low workload. Working stress $(\mathrm{p}=0.042 ; \mathrm{OR}=0.105)$. This implies that if employees have high job stress, then the employee has less productive risk in working 0.105 times greater than employees who have low job stress. So it can be concluded that the most dominant factor affect $\mathrm{Y}$ (productivity) is the work load factor with the effect of 0.303 times.

The result of this research is similar to the previous research conducted by Aprilia (2017) which examined the effect of workload, work stress and motivation on the performance of the Nurses of Ibnu Sina Hospital Pekanbaru, where the results found workload, work stress and work motivation simultaneously have a significant effect on the performance of Nurul Islam Hospital Ibn Sina Pekanbaru. This shows that workload, job stress and work motivation simultaneously have a significant effect on the performance of Nurmah Hospital of Ibnu Sina Hospital Pekanbaru proved true with the value of F arithmetic (134.929)> F table (2.012) and significance $0.000<0.05$.

Work productivity is directly influenced by quality factor and physical ability of employees (workload, motivation and work stress). While supporting facilities such as facilities and infrastructure used, employee welfare and supra means related to government policy and industrial 
relations (leadership with employees, employees with employees) are assessed as indirect influence of work productivity.

In this study workload is the most dominant factor in influencing employee productivity in Bakti Mulia Hospital Muncar environment. According Sunyoto (2012) workload is too much can cause tension in a person so as to cause stress. This can be due to the skill level being demanded too high, the working speed may be too high, the volume of work may be too much and so on.

The inability to overcome the duties imposed by the Bakti Mulia Hospital Muncar management of Banyuwangi Regency can affect the mental, physical, emotional and spiritual health of human beings causing their work productivity to be hampered. Therefore workload and job stress on employees can affect work productivity. While the most dominant actors to employee productivity are the workload. Workload is one aspect that must be considered by every company, because the workload is too much or too light can be one of the factors that affect the high level of prduktivitas work employees in the company.

\section{CONCLUSION}

In this research can be concluded as follows:

1. There is influence of work load to work productivity at Bakti Mulia Hospital Muncar of Banyuwangi Regency . $(\mathrm{p}=0.012 ; \mathrm{OR}=0,314)$.

2. There is the influence of motivation to work productivity in Bakti Mulia Hospital Muncar Banyuwangi $(\mathrm{p}=0.035$; OR $=0,035)$.

3. There is an effect of work stress on work productivity in Bakti Mulia Hospital District Muncar Banyuwang ( $\mathrm{p}=0.03$ 9; $\mathrm{OR}=0,102)$.

4. The most dominant factor affecting employee productivity at Bakti Mulia Hospital Muncar of Banyuwangi Regency is work load ( $\mathrm{p}=0,11$; $\mathrm{OR}=0,303$ ).

\section{SUGGESTION}

\section{For respondents}

To be able to improve work productivity employees need to improve skills and skills so that the work performed rutinya tasks do not feel burdened even more creative and innovative employees.

2. For research sites

Hospital management should consider the workload factor, motivation and work stress that occurs in employees by improving both facilities and infrastructure that support employees in work.

\section{For Further Researchers}

With the limitation of the research, it is hoped that the next researcher will develop this research by researching factors other than work load, motivation and work stress that can affect the work productivity of the employees.

\section{REFERENCES}

Afia, I. (2013). Konstribusi beban kerja, disiplin kerja, hubungan dengan teman sekerja terhadap produktivitas kerja di PT. Viccon Modern Industry. http://jurnalmahasiswa. unesa.ac.id/index.php/jpap/article/view/3942/6473.

Aprilia, F. (2017). Pengaruh Beban Kerja, Stres Kerja Dan Motivasi Kerja Terhadap Kinerja Perawat Rumah Sakit Islam Ibnu Sina Pekanbaru. Jom FEKON Vol.2 No.1 https://media.neliti.com/media/publications/123921.

Dhania, \& Dhini, R. (2010). Pengaruh Stres Kerja, Beban Kerja Terhadap Kepuasan. Kerja (Studi pada Medical Representatif di Kota Kudus). IAIN: Skripsi tidak dipublikasikan. 
Hasibuan, \& Malayu. (2012). Manajemen Sumber Daya manusia. Jakarta: PT Bumi. Aksara.

Hutabarat, E. (2016). Pengaruh motivasi terhadap peningkatan produktivitas kerja karyawan pada PT. Jasa Marga (persero) tbk Medan. https://methonomi.net/index.php/jimetho/article/view/25.

Mangkunegara, A., P. (2012). Manajemen Sumber Daya Manusia. Bandung: PT. Remaja Rosdakarya.

Masna, (2017). Analisis Pengaruh Supervisi Kepala Ruangan, Beban Kerja, Dan Motivasi Terhadap Kinerja Perawat Dalam Pendokumentasian Asuhan Keperawatan Di Rumah Sakit Bhayangkara Makassar. Jurnal Mirai Management Volume 2 No. 2 April $\quad-\quad$ Januari 2017 . http://journal. stieamkop.ac.id/index.php/mirai/article/download/62/62.

Rahman, A., W. (2015). Pengaruh Kompetensi Dan Lingkungan Kerja Terhadap Kinerja Perawat Bagian Rawat Inap Pada Rumah Sakit Umum Daerah (RSUD) Petala Bumi Pekanbaru. Jom FEKON Vol.2 No.1 https://media.neliti.com/media/publications/33811.

Robbins, S., P. \& Judge. (2011). Perilaku Organisasi, Jakarta: Salemba Empat.

Saputri. N., E. (2012). Hubungan antara stres kerja dengan produktivitas kerja karyawan. http://eprints.ums.ac.id/20338/24/02._Naskah_Publikasi.pdf.

Sekarwangi, E., \& Meiyanto. (2014). Pengaruh Stress Kerja dan Keadilan Organisasi terhadap Employee engagement”. Journal of Magister Profesi Psikologi Universitas Gadjah Mada. pp 1-11.

Siagian, \& Sondang, P. (2012). Manajemen Sumber Daya Manusia, Jakarta: Bumi Aksara.

Sumangando, M. (2017). Hubungan beban kerja perawat dengan kejadian Low back pain (LBP) Pada Perawat Pelaksana di RS TK. III R.W Monginsidi Manado. ejoural Keperawatan (e-Kp) Volume 5. https://media.neliti.com/media/publications/110022-ID-hubungan-beban-kerja-perawat-dengan-keja.pdf.

Sunyoto, D. (2013). Dasar-Dasar Manajemen Pemasaran. Yogyakarta: CAPS.

Sutrisno, \& Edy. (2013). Manajemen Sumber Daya Manusia, Edisi Pertama, Jakarta: Kencana.

Suwatno, \& Priansa, D., J. (2011). Manajemen SDM dalam Organisasi. Publik dan Bisnis. Bandung: Alfabeta.

Tarwaka. (2010). Ergonomi Industri. Surakarta: Harapan Press. 